УДК 81’374.80:920

DOI https://doi.org/10.26661/2414-9594-2021-1-7

\title{
«ФАНАТИЧНО ВІДДАНА УКРАЇНІ»: ЖИТТСВИЙ І НАУКОВИЙ ШЛЯХ ГАННИ НАКОНЕЧНОЇ В НІМЕЧЧИНІ
}

\author{
Городиловська Г. П. \\ кандидат філологічних наук, \\ доиент кафедри украӥнської мови \\ Національний університет «Львівська політехніка» \\ вул. Карпінського, 2/4, Львів, Украӥна \\ orcid.org/0000-0002-4960-4599 \\ hhorodylovska@gmail.com
}

Ключові слова: мовознавець

Ганна Наконечна, украӥнська еміграція, біографічні

відомості, наукова і культурна

діяльність, мовознавча

спадщчина.
У статтівисвітленожиттєвийінауковийшлях української вченоїГ.Наконечної, яка в міжвоєнний період емігрувала до Німеччини, де жила й творила до кінця своїх днів. На основі різних джерел (архівних документів, спогадів сучасників, публікацій про вчену) з'ясовано, що професор Г. Наконечна талановитий науковець, педагог і перекладач, яка залишила після себе цікаву лінгвістичну спадщину в різних царинах мовознавчої науки.

Встановлено, що за хронологічним порядком життєвий шлях ученої можна поділити на такі три періоди: перемишльський (18961915 роки); берлінський (1916-1944 роки); мюнхенський (1945-1994 роки). Виявлено, що найбільш продуктивним і багатим у наукових дослідженнях був берлінський період, який дуже позитивно відобразився на іiї кар'єрі. Окреслено мовознавчий доробок Г. Наконечної, який, на жаль, до цього часу є маловідомим для українців, оскільки з їі працями здебільшого можна було ознайомитися лише в архівах. 3'ясовано, що невелика, але дуже цінна частина документів зберігається в архіві Українського вільного університету в Мюнхені (Німеччина).

Зазначено, що багаторічна наукова діяльність лінгвістки присвячена дослідженням 3 лексикографії, діалектології, лінгвогеографії та лінгводидактики. Головними працями вченої є перекладні словники, зокрема "Deutsch-Ukrainisches Taschenwörterbuch" (1939 рік), "PolnischDeutsch und Deutsch-Polnisch: mit einem Anhang der wichtigeren Neubildungen des Polnischen und Deutschen und Erläuterungen zur polnischen Aussprache" (1943 рік), монографія "Ukrainische Mundarten. Südkarpatoukrainisch (Lemkisch, Bojkisch und Huzulisch)" (1940 рік) (у співавторстві з Я. Рудницьким), навчальний посібник "Kurze deutsche Grammatik fur Ukrainer" (1941 рік), які є вагомим внеском вченої в українську лінгвістичну науку. Особливу увагу звернено на кропітку й сумлінну працю Г. Наконечної в царині української діалектології. Проаналізовано зразки діалектологічних анкет-питальників (квестіонарів), які мали велике значення для наукових розвідок авторки.

Відзначено також активну громадянську позицію української вченої, яка була щирою патріоткою, «фанатично відданою Україні», служінню та розвитку якої вона віддала все своє життя. 


\title{
"FANATICALLY DEVOTED TO UKRAINE": LIFE AND RESEARCH WORK OF HANNA NAKONECHNA IN GERMANY
}

\author{
Horodylovska H. P. \\ Candidate of Philological Sciences, \\ Associate Professor at the Department of the Ukrainian Language \\ Lviv Polytechnic National University \\ Karpinskyi str., 2/4, Lviv, Ukraine \\ orcid.org/0000-0002-4960-4599 \\ hhorodylovska@gmail.com
}

Key words: linguist Hanna Nakonechna, Ukrainian emigration, biographical information, scientific and cultural activities, linguistic heritage.
The article outlines the life and research work of the Ukrainian scientist H. Nakonechna, who while the interwar period emigrated to Germany, where she lived and created until her very death. Based on various sources (archival documents, memories of contemporaries, publications about the scientist) it is found out that Professor H. Nakonechna is a talented scientist, teacher and translator who left an interesting linguistic heritage in various fields of linguistics. It is established that the life path of a scientist can be divided into three periods in chronological order: 1) Przemyśl (1896-1915); 2) Berlin (1916-1944); 3) Munich (1945-1994). It is found out that the most productive and the most important scientifically was the Berlin period that was very positive in her career. The linguistic work of $\mathrm{H}$. Nakonechna is outlined, which, unfortunately, has been little known to Ukrainians before, because her works were mainly available only in the archives. It turned out that a small, but a very valuable part of some documents is stored in the archives of the Ukrainian Free University in Munich (Germany).

It is noticed that the long-term scientific activity of the linguist is devoted to the research in lexicography, dialectology, and linguistic geography andlinguodidactics. It is indicated that the main works of the scientist are translated dictionaries, in particular "Deutsch-Ukrainisches Taschenwörterbuch" (1939), "Polnisch-Deutsch und Deutsch-Polnisch: mit einem Anhang der wichtigeren Neubildungen des Polnischen und Deutschen und Erläuterungen zur polnischen Aussprache" (1943), monography "Ukrainische Mundarten. Südkarpatoukrainisch (Lemkisch, Bojkisch und Huzulisch)" (1940) (co-authored with J. Rudnytsky), textbook "Kurze deutsche Grammatik für Ukrainer" (1941), which are significant contribution of the scientist to the Ukrainian linguistics. Special attention is paid to the conscientious work of $\mathrm{H}$. Nakonechna in the field of Ukrainian dialectology. Samples of dialectological questionnaires were analyzed (questionnaires), which were important for the author's scientific work.

The active civil position of the Ukrainian scientist is noted, who was a sincere patriot, "fanatically devoted to Ukraine", she devoted her life to the service and development of Ukraine. 
Постановка проблеми. Одним із найбільших осередків еміграційного життя українців міжвоєнного періоду та часів Другої світової війни була Західна Європа, зокрема Німеччина, де в різних таборах для біженців і «переміщених осіб» (так звані табори Ді-Пі) сконцентрувалися потужні інтелектуальні сили, а саме українські політики, науковці, вчені, діячі культури. Серед таких постатей були й відомі лінгвісти, такі як Василь Лев, Кость Кістяківський, Пантелеймон Ковалів, Зенон Кузеля, Ярослав Рудницький, Юрій Шевельов. Їхнє вимушене перебування в чужій країні було надто важким випробуванням. Кожен із них пройшов тернистий шлях, зіткнувся 3 різними життєвими обставинами, однак продовжував свою наукову діяльність. Будучи за межами батьківщини, ці інтелектуали не переставали служити українській ідеї, брали участь у міжнародних заходах, активно проявляли себе в науковій і культурній сферах.

У когорті згаданих учених $є$ також імена талановитих жінок, що жили й творили в Німеччині, але їхні творчі здобутки, на жаль, залишаються маловідомими, а то й зовсім невідомими широкому загалу в Україні. Серед таких особистостей в українському науковому й культурному житті Німеччини надзвичайно цікавою $є$ постать Ганни Наконечної - видатної української лінгвістки $\mathrm{XX}$ століття, яка за велінням долі опинилася в Німеччині під час першої потужної хвилі української еміграції. Без сумніву, ім'я вченої, її багаторічна наукова діяльність та активна громадянська позиція мають велике значення для історії українського мовознавства, тому заслуговують на особливу увагу сучасних авторів.

Окремі аспекти наукової діяльності Г. Наконечної досліджували лінгвісти М. Зимомря [4], О. Лазаренко [7], принагідно використовували у своїх працях I. Кочан [5], 3. Кузеля [6], Т. НоскоОборонів [8], описували в спогадах Я. Рудницький [9], Я. Стех [10; 11], Ю. Шерех [12], життєві дороги яких так чи інакше перетнулися 3 долею дослідниці. Проте узагальнюючої праці, яка б комплексно розглядала наукову спадщину вченої, в сучасній україністиці ще немає. 3 огляду на це iii творчість потребує всебічного вивчення та грунтовного аналізу в наукових публікаціях.

Мета статті полягає у висвітленні основних віх життєвого та наукового шляху Г. Наконечної, окресленні іiі мовознавчої спадщини, демонстрації внеску вченої в українську лінгвістичну науку.

Виклад основного матеріалу дослідження. Ганна Наконечна (1896-1994) - видатна українська вчена, педагог, перекладач, громадсько-культурний діяч. В Україні мешкала лише в дитячі роки, проте була істинною українкою. Ї̈̈ активна громадянська позиція свідчить про справжній патріотизм, а прагнення допомогти Україні та українцям викликає захоплення.

Життєвий шлях Г. Наконечної був непростим. Емігрантська доля приготувала їй строкату географію поневірянь, зміну країн, місць навчання і праці. 3 часу Першої світової війни вчена емігрувала до Німеччини, і більшу частину свого життя вона прожила за кордоном. Талант цієї дослідниці проявився в різних царинах мовознавства, вона підготувала кількадесят наукових праць 3 лінгвістики, зокрема діалектології, лінгвогеографії, лексикографії та лінгводидактики, які вийшли друком за кордоном.

Оскільки іiї праці зберігалися переважно в архівах, то в радянські часи про неї не писали. Зазначимо, що невелика, але дуже цінна частина документів мовознавиці $є$ в бібліотеці та в архіві Українського вільного університету в Мюнхені (Німеччина). В особовому фонді Г. Наконечної знаходимо, наприклад, перекладний словник "Deutsch-Ukrainisches Taschenwörterbuch" [15], навчальний посібник "Kurze deutsche Grammatik fur Ukrainer" [16], цікаву й оригінальну наукову статтю "Aus der Wortgeographie der ukrainischen Umgangssprache: die Bezeichnungen für den “(Stiefel) Absatz" [14] про вживання форми «обцас» в українській розмовній мові, де через детальну географічну карту представлено поширення цієї лексеми в різних місцевостях України (розвідка опублікована в збірнику на пошану професора, доктора Юрія Шевельова). Окрім цього, в архіві УВУ можна ознайомитися зі взірцем анкети-питальника (квестіонара), який уклала Г. Наконечна для своїх діалектологічних досліджень.

Вивчаючи матеріали про українську вчену, ми з'ясували, що в жодній радянській енциклопедії iï прізвище не згадувалося. Короткі відомості про життєвий шлях та наукову діяльність Г. Наконечної дізнаємося 3 "Encyclopedia of Ukraine", де зазначено таке: "Nakonechna, Hanna [Nakonečna] (Nakonetschna), b 5 May 1896 in Pluhiv, Zolochiv county, Galicia, d? Linguist. In the interwar period she was an associate of the Research Institute of Phonetics and the Ukrainian Scientific Institute in Berlin. After the Second World War she taught Ukrainian at Munich University" [13, с. 527-528]. У вітчизняному виданні інформація про неї з'являється вже в часи незалежності України, і вона фактично збігається 3 вищенаведеною: «Наконечна Ганна (*1896), мовознавець, співр. Досл.-Фонетичного Ін-ту в Берліні, після 1945 року лекторка української мови німецького університету в Мюнхені» [3, c. 1680].

Звертаємо увагу на те, що в електронній версії Енциклопедії сучасної України є стаття М. Зимомрі про Г. Наконечну, у якій чіткіше зазначено дату, місце народження та смерті вче- 
ної: «НАКОНЕЧНА Ганна (05.05.1896, с. Плугів, нині Золочів. р-ну Львів. обл. - 17.10.1994, Мюнхен, похов. у м. Перемишль, нині Підкарп. воєводства, Польща)» [4].

Отже, завдяки цим унікальним виданням ми дізнаємося, що «науковка» Г. Наконечна (як вона любила себе називати) родом із Львівщини. Про те, де вона здобувала середню та вищу освіту, де жила в дитячі роки, де починала свою наукову діяльність, довідуємося 3 «Пропам'ятної книги українських діячів Перемищини XIX - XX століття», автором якої є відомий в Україні та діаспорі п. Ярослав Стех. За висловом самого автора, матеріал про визначну українку є «першою спробою подати творчо-педагогічний портрет Ганни Наконечної» [11, с. 312]. Дослідник зазначає, що «проф. Ганна Наконечна народилася у багатій українській сім'ї в княжому Перемишлі. Від дитячих років любувалася мальовничою природою цього міста, тут вчилася в українських школах і закінчила з великим успіхом українську гімназію» $[10$, с. $312 ; 11$, с. 4]. Стає очевидним, що Ганна, Ганнуся (як її зазвичай називали) з доброї української родини в Перемишлі, свої дитячі роки провела в рідному місті, там же здобула середню освіту в місцевій українській гімназії. Найімовірніше, що після закінчення гімназії студіювала слов'янську філологію у Віденському університеті.

У 1916 році українська дослідниця переїхала до Берліна. «У зовсім ще молодому віці, дівчам, - зазначає відомий славіст Ю. Шерех, - вона [Г. Наконечна$\Gamma$. Г.] в традиціях старої австро-угорської Галичини, ваблена німецькомовною культурою, подалася до Берліна» [12, с. 28], де й почала свою довголітню наукову діяльність у Фонетичному інституті при місцевому університеті Фрідріха Вільгельма і навіть згодом викладала там українську мову. «Як вона $[\Gamma$. Наконечна $-\Gamma . \Gamma$.] стала лекторкою української мови в Берлінському університеті, - пише в спогадах Ю. Шерех, - я ніколи не міг собі добре уявити, але, мабуть, була потреба на таку посаду. Фасмер, провідний славіст міста й країни, завжди мав комплекси провини за те, що не знав української мови, Ганнуся була напохваті» $[12$, с. 28$]$.

Про активну наукову діяльність Г. Наконечної берлінського періоду довідуємося також зі згаданої електронної версії енциклопедії: «У 1925-1927 роках здійснювала фонетичні записи діалектних текстів українських говірок, які зредагував і видав відомий славіст М. Фасмер. У 1930-х роках як співробітник Українського наукового інституту в Берліні досліджувала особливості українських і польських діалектів під керівництвом I. Мірчука» [3].

Саме в цьому науковому закладі $Г$. Наконечна знайомиться зі своїм земляком Я. Рудницьким, який у 1938 році прибув зі Львова до Берліна на запрошення цієї установи для співпраці над укла- данням великого українсько-німецького словника, що його зініціював професор 3. Кузеля. Ось як описує цю подію сам її учасник у спогаді «Мої берлінські роки (1938-1941)»: «Коли я прийшов до його Інституту [на той час очолював інститут професор Д. Вестерманн $-\Gamma$. Г.], за секретарським столом сиділа русява пані 3 діловою міною, й, пізнавши по німецькій мові, що я не німець, запитала: «Ви українець?» «Так, пані». «То можемо говорити по-українському». Й так почалося моє знайомство 3 панею Ганною Наконечною, тоді секретаркою Фонетичного Інституту, фаворизованою професором Фасмером на цьому становищі» [9, с. 113].

Зі спогадів Я. Рудницького ми також дізнаємося про його тісну співпрацю з Г. Наконечною в царині діалектології: «За його [професора Вестерманна $-\Gamma . \Gamma$.] апробатою ми 3 п. Наконечною транскрибували в його Інституті (поза її і моїми «урядовими» годинами) три південно-карпатські тексти: лемківський із Камюнки, бойківський із Ужгорода й гуцульський із Вовчинець 3 відповідною передмовою й діялектологічними поясненнями. Разом 3 п. Наконечною ми піднаходили найрізніших мовлян чи співаків для запису на платівках для фонографічного архіву Вестерманнового Інституту» [9, с. 114]. У результаті цієї довголітньої співпраці ій вдалося у 1940 році видати збірник «Записи діалектних текстів з Прикарпаття».

Подальша праця вчених ще більше зміцнила їхні товариські взаємини, тому мала позитивний результат для розвитку й поширення україністики за кордоном у майбутньому. Вони разом брали участь у Першому міжнародному конгресі з ономастики, організованого проф. А. Доза в Парижі в червні 1938 року, у Комісії для складання словників при Українському науковому інституті в Берліні. Про лексикографічну співпрацю, спільні наукові проєкти професор Я. Рудницький ділиться 3 нами в іншому уривку своїх спогадів: «Співпраця на терені університету 3 п. Наконечною - наша участь як єдиних українців у паризькому конгресі, пізніше, деякі дальші наукові проєкти, як, наприклад, згадані вгорі мої праці, чи іï мала німецька граматика для українців, короткий німецько-український словник для українців, нова редакція німецького і польського підручних словників $<\ldots>$ наблизило нас і затіснило товариські взаємини» $[9$, с. 114].

У 1942 році Г. Наконечна особисто знайомиться 3 українським лінгвістом Ю. Шерехом, який на той час перебував в Пляуені. Про цю несподівану зустріч читаємо в наступному фрагменті: «У Пляуені сталося моє знайомство 3 Ганною Наконечною. Вона їхала з Берліна до Праги й зупинилася в Пляуені, щоб познайомитися. Так вона казала. Я не виключив би іншої формули: їхала до Праги, щоб зупинитися в Пляуені. Я знав ії прізвище 3 
укладеного нею словника - німецько-українського, кишенькового <..> Було їй тоді сорок дев'ять років, вона була на дванадцять років старша від мене $<\ldots>$ Спомин про ці несподівані відвідини лишився надовго в нашому одноманітному пляуенському житті» $[12$, с. 28]. Однак, як зізнається вчений, до свого берлінського помешкання Г. Наконечна ніколи його не запрошувала, але 3 цього часу вони почали листуватися, а вже пізніше відновили особисте знайомство в Мюнхені.

Уже під час тієї зустрічі вчений відчув, що «ії $[Г$. Наконечної - Г. Г.] німецька мова стала куди краща від рідної української. Думала вона вже давно по-німецьки, до своєї мови домішувала раз по раз німецькі слова й звороти і була переконана, що кожному німецькому слову повинно відповідати українське, а коли нема, - треба штучно створити» $[12$, с. 28$]$. Фактично за таким принципом побудований ii «Німецько-український кишеньковий словник». Щоправда, Ю. Шерех у 1942 році в журналі «Український засів» написав негативну рецензію на цей словник, назвавши його «дуже примітивним», «недолугим», «нікудишнім»: «Словник був, просто кажучи, нікудишній. Німецької частини я не рушив, а з української мені було ясно, що впорядниця української мови не знала, - так я більш-менш написав» $[12$, с. 28].

У Берліні вчена прожила майже тридцять років (аж до 1944 року). «Колись секретарка Макса Фасмера, - згадує Ю. Шерех, - вона вже давно оберталася серед німців і белькотіла німецькою мовою краще, ніж своєю рідною українською» [12, с. 261]. Отже, з Берліна разом з іншими українцями Г. Наконечна переїжджає до Мюнхена. Про цю подію в житті української емігрантки мовознавець О. Лазаренко зазначає таке: «Ми не знаємо достеменно, яким чином і $з$ ким долала цей шлях Ганна Наконечна до столиці Баварії, однак від наукової роботи вона не відмовилася і під час цієї подорожі. Існують згадки про те, що у 1944 році Г. Наконечна переїхала з Берліна до Відня до родичів, а пізніше на запрошення Міністерства освіти переїхала до Мюнхена викладати українську мову в місцевому університеті» [7, с. 194]. Від 1946 року «займалася методичною педагогічною працею як лекторка української мови в німецьких університетах» [10, с. 4]. Крім того, що науковець працювала в місцевому Людвіг-Максимиліан університеті, вона також «систематично викладала на УВУ в Мюнхені <..> і добре прислужилася в УВУ до поширення науково- освітньої й культурної праці» [11, с. 312].

Вже у 1951 році в Людвіг-Максимиліан університеті вчена захистила докторську дисертацію "Wortgeographie der ukrainischen Umgangssprache" («Лінгвогеографія української розмовної мови»), а в подальшому працювала на ниві українських діалектологічних досліджень. У 1983 році була учасницею 9-го Міжнародного з'їзду славістів, що проходив у Києві. У межах цього з'їзду провела перекладознавчий семінар з участю українських науковців В. Німчука, В. Марка, Р. Зорівчак, М. Зимомрі.

У Мюнхені Г. Наконечна прожила до кінця своїх днів і померла 17 жовтня 1994 року. Похована в рідному Перемишлі.

Ці важливі відомості з біографії Г. Наконечної допомагають нам окреслити ії життєвий шлях як визначної українки, талановитого педагога, «жінки-науковця, яка пройшла через багато історичних випробувань і яка спромоглася не загубитися у вирі епохальних подій, прислужившись своїми знаннями Україні й українській справі» [7, с. 199].

Окрім наукових зацікавлень вченої, вважаємо за потрібне згадати про неї як жінку-патріота, людину, яка щиро вболівала за долю України й українців. У своїх спогадах «Я - мене - мені... (і довкруги)» Ю. Шерех характеризує ії як «непримиренну, завзяту українську патріотку й ентузіястку визволення України та її самостійности» [12, с. 264].

Про iï «фанатичну відданість Україні» [12, с. 261] свідчить той факт, що вона $з$ усіх сил завжди намагалася допомогти своїм співвітчизникам, які вимушено опинилися в Німеччині. Так, Ю. Шерех із приємністю згадує, що «добрий янгол〉 Г. Наконечна зробила для нього багато послуг і добра, вона дбала про нього, де могла, допомагала - порадою або ділом. Учена знайшла йому кімнату в Мюнхені, в тому самому будинку, де й сама мешкала, перекладала німецькою мовою його писання, постійно підштовхувала до участі в німецькому культурному житті, сприяла німецьким контактам, робила добру славу в німецьких славістичних колах і навіть просувала до німецького журналістичного дебюту [12, с. 261, 264].

Крім того, що Г. Наконечна була щирою патріоткою, їй були притаманні такі риси характеру, як надзвичайна працьовитість, наполегливість у досягненні поставленої мети, принциповість і водночас, як зазначає Ю. Шерех, «вроджена емоційність у стародівочому віці, яка переходила в гістерію, переконати її в чомусь ніхто ніколи не міг <..>, але серце в неї було добре» $[12$, с. 28$]$.

До речі, зі спогаду Я. Стеха «Перемишлянка на тлі Українського Вільного Університету», присвяченого 100-літньому ювілею від дня народження вченої, ми дізнаємося про рідного брата Г. Наконечної - пана I. Наконечного, який «щиро і тепло розказував про свою сестричку Ганну, якою гордився як вченою, але часто підкреслював іiї жіночу красу. Часто коментував також національнопатріотичні листи, які одержував від неї» [10, с. 4].

Життєвий шлях професора Г. Наконечної за хронологічним порядком можна поділити на такі 
три періоди: перемишльський (1896-1915 роки); берлінський (1916-1944 роки); мюнхенський (1945-1994 роки). Вважаємо, що найбільш продуктивним, корисним і багатим у наукових дослідженнях, науковій продукції для Г. Наконечної був берлінський період (1918-1944 роки), який дуже позитивно позначився на іï кар'єрі. Саме в цей час вона написала і видала більшість своїх книг, сформувалась як майбутній вчений та громадсько-культурний діяч.

За цей період учена видала низку своїх праць, серед яких передусім виділяємо лексикографічні праці - перекладні словники. Так, у результаті довголітньої роботи їй вдалося у 1939 році видати в Лейпцигу у видавництві Отто Гаррассовіц "Deutsch-Ukrainisches Taschenwörterbuch", який охоплював близько 10 тисяч слів і витримав декілька видань. У попередніх розвідках ми вже аналізували цю лексикографічну працю [2]. Услід за цим виданням вийшов друком словник "Polnisch-Deutsch und Deutsch-Polnisch: mit einem Anhang der wichtigeren Neubildungen des Polnischen und Deutschen und Erläuterungen zur polnischen Aussprache" [17].

У 1941 році в тому самому видавництві вийшов iii посібник "Kurze deutsche Grammatik fur Ukrainer", який став корисною навчальною книгою насамперед для тих українців, які самостійно вивчали німецьку мову [16].

У співавторстві з професором Я. Рудницьким мовознавець Г. Наконечна опублікувала монографію "Ukrainische Mundarten. Südkarpatoukrainisch (Lemkisch, Bojkisch und Huzulisch)" [18], що була опрацьована на основі грамофонних платівок і надрукована в Ляйпцигу 1940 року. Також вона допомогла Я. Рудницькому записати і видати грамофонні платівки до «Підручника української мови (для німців)». Окрім вищеназваних праць, вчена опублікувала численну кількість методичних статей, написала десятки лінгвістичних розвідок, у яких багато уваги приділяла лінгвогеографічним дослідженням української лексики $[11$, c. 132]. Особливе враження справляє кропітка й відповідальна праця Г. Наконечної в царині української діалектології та лінгвогеографії. Цю широку діяльність ученої засвідчують архівні документи мюнхенського періоду, що зберігаються в особовому фонді вченої. Серед цих паперів $є$ зразки сумлінно підготовлених мовознавчих анкет-питальників, за допомогою яких авторка досліджувала український діалектний матеріал. В одній із таких анкет Г. Наконечна звертається до респондентів і просить їх зазначити своє прізвище, вік, місце проживання (місто, село, повіт) та професію. У зверненні «Порівнюйте з образками!» авторка пише: «Прошу ласкаво подати, як називали в щоденному мововжитку у Вашому місті, чи околиці, зазначені в цій анкеті частини дому, предмети вжитку, частини одягу тощо, i подати їх вимову і наголос [підкреслення Г. Наконечної - Г. Г.]. Якщо вживали кілька термінів на одну й ту саму річ, то прошу найбільш поширене слово підкреслити і зазначити, хто вживав ці другі слова, село, чи старша генерація? Всі ваші пояснення і спостереження для цієї праці дуже цінні. Для прикладу: ч. 2 комин, димар/переважно село/, труба /ст. ген., мало/, бовдур/на селі це частина комина в хаті» [1]. Зрозуміло, що для дослідниці дуже важливими $є$ правдиві відповіді респондентів, необхідні для іiї наукових розвідок.

У розглянутій діалектологічній анкеті подано 9 груп лексики з відповідною кількістю назв, що стосуються побутової сфери людського життя. Наприклад: I. Будинок, дім-осібняк; II. Мешкальна кімната, світлиця; III. Робоча кімната, кабінет; IV. Спальня, спальна кімната; V. Лазничка, лазня, ванна, баня; VI. Кльозет, виходок, уборна, вбиральня; VII. Кухня; VIII. Електричне приладдя; IX. Чоловіча і жіноча одежа, мужеський і жіночий одяг. Зазначимо, що кожна $з$ таких груп ілюстрована картинкою (образком) і містить позначені цифрами регіональні лексеми, до яких поставлені запитання «Котре 3 них?», «Може, інакше?». Так, перша група «Будинок, дім-осібняк» містить 18 пунктів, поряд з якими розміщено по 2-4 регіональні лексеми, наприклад: 1. гребінь, хребет, коник; 2. комин, димар, бовдур, труба; 3. драбина, лісниця; 4. горище, горіще, стрих, підверх, чердак; 5. причілок, фронтон, передня стіна; 6. мансарда, горище, піддашшя; 7. маркіза, зонт, навіс; 8. жалюзія, жалюзі, штори; 9. балькон, веранда, галерка; 10. жалюзія, віконниця, хвильонка; 11. еркерна кімната, веренда; 12. підвіконня, парапет, лутка, підвіконник; 13. сутерени, підвал, підвальне помешкання; 14. ринва, стік, дощова труба; 15. ганок, крильце; 16. смітник, мусорниця; 17. ліхтар, лихтар, фонар; 18. дах, крівля, криша, стріха [1]. На підставі цього зібраного матеріалу вчена-мовознавець досліджувала дійсний стан діалектного мовлення в різних місцевостях України.

В іншому зразку-квестіонарі з їі ж підписом Г. Наконечна звертається до респондентів 3 проханням допомогти їй у збиранні діалектного матеріалу, у якому часто вживані слова слід підкреслювати двома лініями, а рідше вживані - однією. Ось як вона про це пише: «Високоповажний Пане! Прошу ласкаво подати докладно [усі підкреслення в цьому тексті Г. Наконечної - Г. Г.], як у Вашій околиці (в місті) українська інтелігенція нижче подані предмети в буденному житті означає (ла). Підходячі слова прошу підчеркнути (гл. вище). Оскільки Вам інші, тут не подані вирази й очеркнення на одну й ту саму річ відомі, прошу 
ïx виписати і подати, в якій околиці, сфері і в якої генерації вони стрічаються. Якщо мова старшої генерації різниться від мови молодшої, прошу подати обі форми. Має якесь, тут подане, слово у Вас інше значення, прошу дуже це докладно пояснити (напр., у нас «котлєтка» це $\epsilon . .$. , а «биток» це м'ясо..., а «беффіле» - це є у нас). Прошу дуже старатися бути об'єктивним і не подавати чисто українських слів і форм, коли Ви їх в дійсности в «поточній» мові не вживаєте. Прошу писати по-українськи і по змозі зазначати акценти» [1]. На думку вченої, метою збирання цього матеріалу $є$ «дослідження географічного розположення певних слів на одно й то само поняття в українській інтелігентській мові, етимологія цих слів і ïx походження (культурні впливи тощо)» [1]. За швидке заповнення цієї анкети $Г$. Наконечна наперед щиро дякує.

Як припускає О. Лазаренко, «найімовірніше, що «квестіонари» укладала і замовляла в друкарні у кількості 600 примірників сама Г. Наконечна, дбаючи про детальність і грунтовність відповідей, оскільки це дуже багато важило для правдивого результату наукових пошуків» [7,c.199].Запропонованийзразок-квестіонармістить 110 німецьких лексем, поряд з якими подано від двох до декількох регіональних українських відповідників. Absatz: обиас, каблук, закаблук, корок, підбор; Wakd-Erdbeeren: позьомки, сунииі, ягоди, клубника, лісові ягоди, земляника; Perlenkette: коралі, перли, буси, намисто, ожерелля, монисто; Schnupfen: катар, нежит, нежать, насмарк, бутуран, тушкір; Wäsche /reine/: білля, білизна, більо, иматє, хусти, платє; Zimmerdecke: cyфim, стеля, пляфонд, потолок, повала [1].

Варто зазначити, що на підставі діалектних матеріалів про лексему "absatz" Г. Наконечна у 1971 році опублікувала статтю про позначення цієї назви в українській розмовній мові, у якій представила детальну географічну карту поширення і функціонування форм обияс, каблук, закаблук, корок, підбор на теренах України [14].

Висновки. Отже, різні джерела (архівні документи, спогади сучасників, публікації про вчену) засвідчують, що професор Г. Наконечна прожила довге та плідне життя. 3 юних літ і до останніх своїх днів вона постійно перебувала на чужині й серед чужого оточення, але не переставала працювати на користь української науки, вкладаючи в це всі свої сили і знання.
Вивчення біографічних відомостей вченої дало змогу поділити ii життєвий шлях на такі три періоди: перемишльський (1896-1915 роки); берлінський (1916-1944 роки); мюнхенський (1945-1994 роки). Безперечно, найбільш продуктивним і багатим на наукові дослідження та культурні події був берлінський період, який позитивно вплинув на іiі кар'єру.

Як видатний український мовознавець, талановитий педагог і перекладач Г. Наконечна залишила після себе цікаву лінгвістичну спадщину, присвячену різноаспектним дослідженням 3 лексикографiї, діалектології, лінгвогеографії та лінгводидактики. Вона, незважаючи на несприятливі умови для наукової праці, має значний науковий доробок у цих царинахмовознавства, аджеуклаланизкусловників, зокрема "Deutsch-Ukrainisches Taschenwörterbuch" (1939 рік), "Polnisch-Deutsch und Deutsch-Polnisch: mit einem Anhang der wichtigeren Neubildungen des Polnischen und Deutschen und Erläuterungen zur polnischen Aussprache" (1943 рік), видала монографію "Ukrainische Mundarten. Südkarpatoukrainisch (Lemkisch, Bojkisch und Huzulisch)" (1940 рік) (у співавторстві з Я. Рудницьким), для якої дуже ретельно збирала діалектний матеріал, підготувала навчальний посібник "Kurze deutsche Grammatik fur Ukrainer” (1941 рік), написала десятки наукових і методичних статей, які $€$ помітним внеском в українську лінгвістичну науку.

Особливої уваги заслуговує кропітка й відповідальна праця Г. Наконечної як ученого-діалектолога, яка ретельно готувала анкети-питальники (квестіонари) для своїх наукових розвідок. Аналіз цих анкет засвідчує детальність і грунтовність відповідей респондентів, що було дуже важливим для правдивого результату лінгвістичних досліджень.

Г. Наконечна проявила себе не лише цікавим науковцем, але й щирим патріотом і людиною, яка дуже вболівала за долю України, вона 3 усіх сил завжди намагалася допомагати українцям, що вимушено опинилися за межами своєї батьківщини. Саме тому постать Г. Наконечної як жінки-науковця, жінки-патріота варта того, щоби було створене комплексне дослідження iї наукового доробку, а сама вчена цілком заслуговує глибокої пам'яті та пошани від українського народу.

Перспективу наукових розвідок убачаємо в подальшому фаховому опрацюванні наукової спадщини Г. Наконечної та іiі популяризації в Україні і світі.

\section{ЛІТЕРАТУРА}

1. Архів Українського Вільного Університету. Особовий фонд Ганни Наконечної.

2. Городиловська Г. Ганна Наконечна як лексикограф. Актуальні питання гуманітарних наук : міжвузівський збірник наукових праць молодих вчених Дрогобицького державного педагогічного університету імені Івана Франка. Вип. 31. Т. 1. Дрогобич : Видавничий дім «Гельветика», 2020. С. 302-308.

3. Енциклопедія українознавства : в 14 т. / гол. ред. В. Кубійович. Львів : Молоде життя, 1996. Т. 5 : Місто - Перемышлянинъ. С. 1680. 
4. Зимомря М., Зимомря I. Наконечна Ганна. Енциклопедія сучасної України / гол. редкол.: І. Дзюба, А. Жуковський, М. Железняк та ін. Київ : Інститут енциклопедичних досліджень НАН України, 2019. URL: http://esu.com.ua/search_articles.php?id=71757 (дата звернення: 08.04.2021).

5. Кочан I. Українське термінознавство 1940-1950-х років. Вісник Національного університету «Львівська політехніка». Серія «Проблеми української термінологї̈». 2011. № 709. С. 74-78.

6. Кузеля 3. Історичний розвиток і сучасний стан українського словництва. Збірник на пошану Зенона Кузелі / за ред. В. Янева. Париж ; Нью-Йорк ; Мюнхен ; Торонто ; Сідней, 1962. С. 217-235.

7. Лазаренко О. «З України треба йти з Україною»: науковий шлях Ганни Наконечної в Німеччині. Ucraina magna. 2017.Vol. II. C. 193-201.

8. Носко-Оборонів T. Ярослав Богдан Рудницький. Оттава, 1992. 48 c. URL: http://diasporiana.org.ua/ ukrainica/6522-nosko-oboroniv-t-yaroslav-bogdan-rudnitskiy (дата звернення: 09.04.2021).

9. Рудницький Я. Мої берлінські роки (1938-1941). В. Ярім, М. Сулима. Украӥнці в Берліні 1918-1945 : пропам'ятний збірник доповідей і спогадів з життя і діяльності українців у Берліні з нагоди 3'їзду 5-го вересня 1981 року в Шератон-готелі в Торонті, Канада. Торонто, 1996. С. 111-120.

10. Стех Я. Перемишлянка на тлі Українського Вільного Університету. Народна воля. 1996. Ч. 20 (16 травня). С. 4.

11. Стех Я. Пропам'ятна книга українських діячів Перемищини XIX - XX століть. Збірник есеїв. 2006. Ч. 1. С. 312.

12. Шерех Ю. Я - мене - мені ... (і довкруги). Спогади. 2. В Європі. Харків : Фоліо, 2012. 316 с.

13. Encyclopedia of Ukraine / Danylo Husar Struk. Toronto, Buffalo, London : University of Toronto Press, 1993. Vol. III ed. P. 527-528.

14. Nakonetschna H. Aus der wortgeographie der ukrainischen umgangssprache: die Bezeichnungen für den "(Stiefel) Absatz". Symbolae in honorem Georgii Y. Shevelov. München : Ukrainian Free University, 1971. Vol. 7. P. 321-328.

15. Nakonetschna H. Deutsch-Ukrainisches Taschenwörterbuch. Leipzig : Otto Harrassowitz, 1939. 176 p.

16. Nakonetschna H. Kurze deutsche Grammatik fur Ukrainer. Leipzig : Otto Harrassowitz, 1941. 78 p.

17. Nakonetschna H. Polnisch-Deutsch und Deutsch-Polnisch: mit einem Anhang der wichtigeren Neubildungen des Polnischen und Deutschen und Erläuterungen zur polnischen Aussprache. Berlin, 1943.

18. Nakonetschna H., Rudnyćkyj J. Ukrainische Mundarten. Südkarpatoukrainisch (Lemkisch, Bojkisch und Huzulisch). Leipzig : Otto Harrassowitz, 1940.

\section{REFERENCES}

1. Arkhiv Ukrainskoho Vilnoho Universytetu [Archive of the Ukrainian Vilnius University]. Osobovyi fond Hanny Nakonechnoi.

2. Horodylovska H. (2020) Hanna Nakonechna yak leksykohraf [Hanna Nakonechna as a lexicographer]. Aktualni pytannia humanitarnykh nauk: mizhvuzivskyi zbirnyk naukovykh prats molodykh vchenykh Drohobytskoho derzhavnoho pedahohichnoho universytetu imeni Ivana Franka. Vol. 31. Tom 1. Drohobych: Vydavnychyi dim "Helvetyka". P. 302-308.

3. Entsyklopediia ukrainoznavstva (1996) [Encyclopedia of Ukrainian Studies]. (T. 5: Misto - Peremyshljanin, s. 1680); Lviv: Molode zhyttia.

4. Zymomria M., Zymomria I. (2020) Nakonechna Hanna. Entsyklopediia suchasnoi Ukrainy [Encyclopedia of Modern Ukraine: electronic version] / hol. redkol.: I. Dziuba, A. Zhukovskyi, M. Zhelezniak ta in. Kyiv: Instytut entsyklopedychnykh doslidzhen NAN Ukrainy. URL: http://esu.com.ua/search_articles. php?id=71757.

5. Kochan I. (2011) Ukrainske terminoznavstvo 1940-1950-kh rokiv [Ukrainian terminology of 19401950 s.]. Visnyk Natsionalnoho universytetu "Lvivska politekhnika". Ser. "Problemy ukrainskoi terminolohii”. № 709. P. 74-78.

6. Kuzelia Z. (1962) Istorychnyi rozvytok i suchasnyi stan ukrainskoho slovnytstva [Historical development and current of Ukrainian vocabulary]. Zbirnyk na poshanu Zenona Kuzeli. V. Yaneva (red.). Paris, New York, Munich, Toronto, Sydney. P. 217-235.

7. Lazarenko O. (2017) "Z Ukrainy treba yty z Ukrainoiu": Naukovyi shliakh Hanny Nakonechnoi v Nimechchyni ["From Ukraine we must go with Ukraine": Anna Nakonechna scientific path in Germani]. Ucraina magna. Kyiv. Vol. II. P. 193-201.

8. Nosko-Oboroniv T. (1992) Yaroslav Bohdan Rudnytskyi [Yaroslav Bohdan Rudnytsky]. Ottava. Vylucheno iz http://diasporiana.org.ua/ukrainica/6522-nosko-oboroniv-t-yaroslav-bogdan-rudnitskiy.

9. Rudnytskyi Ya. (1996) Moi berlinski roky (1938-1941) [My Berlin (1938 -1941]. U kn.: V. Yarish, M. Sulyma. Ukraintsi v Berlini 1918-1945. Propamiatnyi zbirnyk dopovidei i spohadiv z zhyttia i dijalnosty 
ukraintsiv u Berlini z nahody Zizdu 5-ho veresnia 1981 r. v Sheraton hoteli v Toronti, Kanada. Toronto. P. 111-120.

10. Stekh Ya. (1996) Peremyshlianka na tli Ukrainskoho Vilnoho Universytetu [Przemyśl on the background of the Ukrainian Free University]. Narodna volia. Ch. 20 (16 travnia). P. 4.

11. Stekh Ya. (2006) Propamiatna knyha ukrainskykh diiachiv Peremyshchyny XIX - XX stolit [Commemorative book of Ukrainian figures of Peremyshl region of the XIX - XX centuries]. Zbirnyk eseiv. Chastyna persha. Lviv: Spolom. P. 312.

12. Sherekh Yu. (2012) Ya - mene - meni ... (i dovkruhy) [I - me - me... (and around)]. Spohady. 2. V Evropi. Kharkiv: Folio. 316 p.

13. Encyclopedia of Ukraine (1993) / Danylo Husar Struk. Toronto, Buffalo, London: University of Toronto Press. Vol. III ed. P. 527-528.

14. Nakonetschna H. (1971) Aus der wortgeographie der ukrainischen umgangssprache: die Bezeichnungen für den "(Stiefel) Absatz" [From the geography of the colloquial Ukrainian language: the terms for the "(boot) heel"]. Symbolae in honorem Georgii Y. Shevelov. München: Ukrainian Free University. Vol. 7. P. 321-328.

15. Nakonetschna H. (1939) Deutsch-Ukrainisches Taschenwörterbuch [German-Ukrainian pocket dictionary]. Leipzig: Otto Harrassowitz. 176 p.

16. Nakonetschna H. (1941) Kurze deutsche Grammatik fur Ukrainer [Short German grammar for Ukrainians]. Leipzig: Otto Harrassowitz. 78 p.

17. Nakonetschna H. (1943) Polnisch-Deutsch und Deutsch-Polnisch: mit einem Anhang der wichtigeren Neubildungen des Polnischen und Deutschen und Erläuterungen zur polnischen Aussprache [PolishGerman and German-Polish: with an appendix of the more important new forms of Polish and German and explanations of the Polish pronunciation]. Berlin.

18. Nakonetschna H., Rudnyćkyj J. (1940) Ukrainische Mundarten. Südkarpatoukrainisch (Lemkisch, Bojkisch und Huzulisch) [Ukrainian dialects. South Carpatoukrainian (Lemkish, Boykish and Hutsul)]. Leipzig: Otto Harrassowitz. 